\title{
PLOT AND CHARACTER IN GALATIANS 1-2
}

\author{
Timothy Wiarda
}

\begin{abstract}
Summary
Analysis of plot structure and Paul's self-characterisation contributes to the ongoing debate concerning the function of the narrative material in Galatians 1 and 2. While such analysis confirms the traditional view that this material aims to establish the credentials of Paul and his gospel, it shows that these chapters also serve a strong paradigmatic purpose. It more sharply defines both the traditional view (by clarifying each episode's distinct contribution to Paul's defence of his gospel and authority) and the example view (by identifying the precise aspects of Paul's life that he presents for imitation).
\end{abstract}

\section{Introduction}

In this study I wish to bring some of the interests and perspectives of narrative criticism to bear on the autobiographical material of Galatians 1:13-2:21, giving special attention to plot structure and characterisation.

While analysis of plot and character has its intrinsic interest, it may also shed light on the rhetorical functions of this section of Galatians a matter that has engendered significant debate among interpreters. For this reason before beginning narrative investigation I will briefly survey the principal ways interpreters have understood Paul's rhetorical aims. Scholars have taken three broad approaches. Those who adopt what might be called the traditional view conclude that Paul seeks to demonstrate the legitimacy of his gospel and/or apostolic ministry. They connect Paul's narrative tightly to his immediately preceding assertion that he did not receive his gospel from any human person but 'through a revelation of Jesus Christ' (1:12), and thus see the central issue to be the source of Paul's message and apostleship. He defends 
the divine origin of both by stressing his independence from the Jerusalem church; this is necessary, it is usually assumed, because Paul must respond to the charge that his message and authority derive only from the Jerusalem apostles. ${ }^{1}$ Those who share this basic perspective, however, display two diverging tendencies. A number of influential interpreters treat Paul's entire autobiographical narrative as a more-orless unified whole serving one central purpose: to demonstrate the claim of 1:12 that Paul did not receive his gospel from human sources. ${ }^{2}$ Other scholars give greater attention to the distinctiveness of each of the main subsections of Paul's narrative, discerning a different rhetorical purpose for each. This latter group links Paul's concern to demonstrate his gospel's divine origin specifically to the first part of his narrative (1:13-24). They see him moving on to other issues in the material that follows. Lagrange provides a particularly clear example: Paul first answers the charge that he is simply a delegate of the Jerusalem apostles (1:13-24), then the charge that he had departed from the Jerusalem gospel $(2: 1-10)$, then the charge that he had compromised the truth for practical reasons $(2: 11-21){ }^{3}$

A second approach, both similar and antithetical to the first, holds that Paul describes his life and experience to illustrate the tradition-

1 Interpreters differ on some of these points. Some see Paul primarily defending his apostleship, others his gospel. Some think Paul addresses specific charges, others not. Some think the charge against Paul is that he had not received a commission from Jerusalem (e.g. J. Calvin, Commentaries on the Epistles of Paul to the Galatians and Ephesians, in Calvin's Commentaries vol XXI [Grand Rapids: Baker, 1981]: 16; E. D. Burton, The Epistle to the Galatians [Edinburgh: T. \& T. Clark, 1921]: 35).

2 See, e.g. H. D. Betz, Galatians (Philadelphia: Fortress, 1979): 16-18; Burton, Galatians: 35-102; J. D. G. Dunn (who excludes the Antioch incident from this function), The Epistle to the Galatians (Peabody: Hendrickson, 1993): 55, 87; Richard N. Longenecker, Galatians (Dallas: Word, 1990): 20. In the case of some commentators (Burton is a strong example) the motif of Paul's independence may thus be seen in 2:1-10 and 2:11-14 as well as in 1:13-24. Those who relate the structure of Galatians to the conventions of ancient rhetoric are perhaps encouraged toward a single-function view of the autobiographical section by defining it as a formal narratio.

3 Saint Paul Épitre aux Galates (Paris: J. Gabalda, 1950): 9. See also (with variations) P. Bonnard, L'Épître de Saint Paul aux Galates (Neuchâtel: Delachaux \& Niestlé, 1953): 26-27. Though some interpreters highlight a single function and others multiple functions, in many cases this is a matter of emphasis rather than clear rejection of the alternative. Some identify a distinct function for each of the three principle subsections while nevertheless connecting the whole to Paul's claim in 1:12 (e.g. F. Mussner, Der Galaterbrief [Freiburg: Herder, 1974]: 77; H. Schlier, Der Brief an die Galater [Göttingen: Vandenhoeck \& Ruprecht, 1951]: 21-48). 
transcending nature of the gospel. ${ }^{4}$ Like advocates of the traditional view, interpreters who adopt this perspective discern a close tie between Paul's narrative and his preceding assertions concerning the non-human nature and origin of his gospel. ${ }^{5}$ But they deny Paul is defending his authority or in any way giving the Galatians external grounds for accepting his message. Instead, he simply wishes to demonstrate how the gospel works - the gospel breaks into a person's life with revelatory power, totally apart from human persuasion or authority. Those who interpret Paul's narrative along these lines stress what is paradigmatic in his experience of encountering Christ and coming to faith rather than what is uniquely apostolic. ${ }^{6}$

Many who follow this second approach also speak of Paul narrating his life as an example of the transforming power of the gospel..$^{7}$ For such interpreters this is simply an additional way in which Paul highlights the gospel's supernatural character: at some points his narrative accents the gospel's revelatory power, at other points its transforming power. Where does the narrative highlight transformation? First and foremost in 1:13-24, it is argued, where an enemy of the church becomes a preacher of the gospel; then also in 2:1-10 (according to some), where the Jerusalem leaders are moved to endorse Paul's ministry; ${ }^{8}$ and in 2:11-14, where Paul boldly upholds the right of Jews and Gentiles believers to eat together.

While often agreeing that Paul portrays his life to testify to the gospel's life-changing power, a third group of interpreters perceives yet another dimension of his self-portrait. These scholars argue that Paul presents his actions and responses as a model for imitation. The qualities Paul wants the Galatians to emulate are variously described: ${ }^{9}$

4 Representatives include, B. Lategan, 'Is Paul Defending His Apostleship In Galatians?' NTS 34 (1988): 411-30; D. Lührmann, Galatians (Minneapolis: Fortress, 1992): 16-19; J. L. Martyn, Galatians (New York: Doubleday, 1997): 23-25, 152; J. H. Schütz, Paul and the Anatomy of Apostolic Authority (Cambridge: CUP, 1975): 12629.

5 Lategan sees the link exclusively with the nature of the gospel (the focus of 1:11), not its origin ('Paul': 419-20).

6 'The autobiographical references are a paradigm not only of the apostle, but of the Christian as such' (Schütz, Paul: 134).

7 E.g. Lategan, 'Paul': 425; Martyn, Galatians: 155-58; Schütz, Paul: 133.

8 Martyn, Galatians: 201; Schütz, Paul: 142-44.

9 Depending in part on which part of the narrative is in view. Even scholars who think Paul's primary aim is to defend his apostolic status will often acknowledge secondary elements of intentional modelling at some points in his narration. 
loyalty to the gospel and resilience in the face of pressure, ${ }^{10}$ singleminded response to the gospel and commitment to its exclusive claims, ${ }^{11}$ abandonment of law-dependence and adherence to gospel freedom, ${ }^{12}$ being decentered or destabilised by God, ${ }^{13}$ seeking to please God rather than people, ${ }^{14}$ personal integrity and consistency,,$^{15}$ a life reflecting the character of the gospel. ${ }^{16}$ Some interpreters perceive direct parallels between certain aspects of Paul's experience - the kinds of pressure he faced and had to resist, for instance - and the situation facing his Galatians readers. Parts of Paul's story may then be seen as deliberate analogies to or dramatisations of the Galatian crisis. ${ }^{17}$ Variations of this third general perspective are becoming increasingly popular, with scholars often appealing to precedents in Greco-Roman autobiographical materials. ${ }^{18}$

10 S. Fowl, 'Learning to Narrate Our Lives in Christ', in C. Seitz (ed.), Theological Exegesis: Essays in Honor of Brevard S. Childs (Grand Rapids: Eerdmans, 1999): 346; B. Longenecker, The Triumph of Abraham's God (Nashville: Abingdon, 1998): 14849; R. Longenecker, Galatians: cxvi.

11 B. Gaventa, 'Galatians 1 and 2: Autobiography as Paradigm', NovT 28 (1986): 313, 322.

12 Gaventa, 'Galatians': 322; Fowl, 'Learning': 347; Lyons, Pauline Autobiography: Toward a New Understanding (Atlanta: Scholars, 1985): 171-72.

13 Fowl, 'Learning': 344.

14 Gaventa, 'Autobiography': 314; R. Hall, 'Historical Inference and Rhetorical Effect: Another Look at Galatians 1 and 2', in D. Watson, Persuasive Artistry: Studies in New Testament Rhetoric in Honor of George A. Kennedy (Sheffield: JSOT, 1991): 318.

15 Fowl, 'Learning': 346.

16 J. Hester, 'Placing the Blame: The Presence of Epideictic in Galatians 1 and 2', in Watson (ed.), Artistry: 282, 297-99.

17 E.g. P. Koptak, 'Rhetorical Identification in Paul's Autobiographical Narrative: Galatians 1.13-2:24', JSNT 40 (1990): 98-99; B Witherington III, Grace in Galatia: A Commentary on Paul's Letter to the Galatians (Grand Rapids: Eerdmans, 1998): 23. Marius Victorinus's comments on 2:11-14 represent an early version of this view (see the discussion in S. Cooper, 'Narratio and Exhortatio in Galatians According to Marius Victorinus Rhetor', ZNTW 91 [2000]: 125). M. Nanos, on the other hand, denies that Paul's examples serve as analogies to the Galatian situation (The Irony of Galatians: Paul's Letter in First-Century Context [Minneapolis: Fortress, 2002]: 6467).

18 Some interpreters think Paul calls attention to his personal ethos not simply as a model for imitation, but also to establish his credibility, and therefore that of his message, in the eyes of his readers (e.g. Hall, 'Historical': 318-19; Lyons, Autobiography: 225). This suggestion has a measure of affinity with the traditional approach, which sees Paul defending his authority. 


\section{Some Presuppositions}

As we begin to examine plot and character it is necessary to define terms and methodological assumptions. 'Plot' refers to the ordering of events within a story. Though recent theorists are often reluctant to prescribe the kind of order that story events must have, there seems to be broad agreement on the general features that mark most human storytelling. First, almost all theorists would say that proper plots those that result in the kind of narratives that cultures throughout history have recognised as successful stories - involve a temporal sequence of events. ${ }^{19}$ Second, plot events are normally linked by causeand-effect. ${ }^{20}$ Third, satisfying plots will raise expectation, making readers or listeners want to know what happens next and drawing them forward to a recognisable outcome. ${ }^{21}$ Fourth, most plots involve some form of tension moving toward some kind of resolution. ${ }^{22}$ While more

19 See, e.g. S. Lanser, 'Plot', in A. Preminger and T. Brogan (eds), The New Princeton Encyclopedia of Poetry and Poetics (Princeton: Princeton University Press, 1993): 916. This is rarely disputed, though Seymour Chatman points out that a strong sense of temporal order is more important in the traditional narrative of resolution than in the modern plot of revelation (Story and Discourse: Narrative Structure in Fiction and Film [Ithaca: Cornell University Press, 1978]: 48).

20 See Robert Scholes, Semiotics and Interpretation (New Haven: Yale University Press, 1982): 63. Lanser notes that some modern theorists see causality as a culturally influenced, less-than-universal plot feature ('Plot': 917).

21 'Children very early develop what one might call a basic narrative competence: demanding stories, they know when you are trying to cheat them by stopping before reaching the end. So the first question for the theory of narrative might be, what do we implicitly know about the shape of stories that enables us to distinguish between a story that ends 'properly' and one that doesn't, where things are left hanging?' (Jonathan Culler, Literary Theory: A Very Short Introduction [Oxford: Oxford University Press, 1997]: 79). Peter Brooks speaks of 'the play of desire in time that makes us turn pages and strive toward narrative ends' (Reading for the Plot: Design and Intention in Narrative [Cambridge, MA: Harvard University Press, 1984]: xiii). Cf. Scholes: 'As a perceived narrative begins to imply a special kind of pointedness or teleology, we recognize that it is a story...' (Semiotics: 60).

22 Though not all theorists emphasise conflict and resolution (some favour related concepts such as transformation or reversal), it is a central feature of most stories. Seymour Chatman recognises that in 'the traditional narrative of resolution [as opposed to some $20^{\text {th }}$ century character-oriented fiction], there is a sense of problemsolving, of things being worked out in some way, of a kind of ratiocinative or emotional teleology' (Story and Discourse: Narrative Structure in Fiction and Film [Ithaca: Cornell University Press, 1978]: 48). Noting that not all biblical plots revolve around conflict, Leland Ryken nevertheless considers it 'a safe rule of interpretation always to look first for plot conflict(s)' (Words of Delight: A Literary Introduction to the Bible [Grand Rapids: Baker, 1987]: 62). See also Shimon Bar-Efrat, Narrative Art in the Bible (Sheffield Academic, 1989): 94. 
could be said, these four plot features are widely recognised. We will look for them in our analysis of Galatians 1-2.

'Characterisation' is simply the way characters are portrayed. Traits will either emerge in and through the events of the plot itself as actions reveal the qualities of the characters, or be given more directly through the narrator's own comments. In the latter case the elements of character portrayal may be said to stand alongside the actual plot events; nevertheless, in well-unified stories they will normally explicate or somehow contribute to the audience's understanding of the plot. Characterisation, then, is usually closely connected to plot. But it does not have to be. Traits, values, or status can be depicted in plotless narration as well as in carefully structured stories. This means that our analysis of characterisation in Galatians 1-2 will not totally depend on our success in delineating clear plot structures.

Two important presuppositions underlie this study. One is that both Paul as a narrator and the Galatians as his audience would have been sensitive to the impact of plot and characterisation as these have been described above. ${ }^{23}$ Modern scholars must guard against the temptation to impose foreign frames of reference on NT texts, of course. But I do not think that is a difficulty here. Despite the variety of narrative conventions and genres that have developed through human history, the basic elements of good story structure seem to be culturally widespread. ${ }^{24}$ Both the OT and the Gospels, for instance, are filled with narratives in which events are causally connected, expectations are aroused, events move toward an end, and conflicts find resolution. So is classical and Hellenistic literature, and so are the storytelling traditions of peoples around the world. Something similar can be said

23 Which is not to say that either Paul or his audience would have analysed these matters or even consciously thought about them.

24 Scholes offers the opinion that sensitivity to basic story structures (perception of causality, expectation aroused by a story's implied pointedness or teleology) is learned behaviour, but 'based on a predisposition or potential of the human species to acquire this particular kind of behavior.' He says that even modern attempts to break away from this 'narrativity' nevertheless depend upon it and could not function without it (Semiotics: 62-64). Cf. Culler, Literary Theory: 79; and Peter Brooks: 'Children quickly become virtual Aristotelians, insisting upon any storyteller's observation of the "rules," upon proper beginnings, middles, and particularly ends' (Reading for the Plot: Design and Intention in Narrative [Cambridge, MA: Harvard University Press, 1984]: $3)$. Even if we prefer to think in less universal terms, the four plot features highlighted above are clearly evident within ancient Greek and Hebrew cultural traditions. With respect to the Greek milieu this is true even at the level of conscious theory, as seen in Aristotle's Poetics. 
about the narrative depiction of character. While it is true that cultural traditions vary in important ways (some favour complexity and development in characterisation, others tend to present flat and static characters; some highlight individual qualities, others typical traits), the intentional shaping of character through portrayed action and direct comment is not restricted to a narrow range of cultures. A further observation on plot structuring and character portrayal is that these basic elements of narrative practice are not limited to specialised venues and occasions. ${ }^{25} \mathrm{I}$ assume, then, that when Paul narrated events he was never free from intuitive sensitivity to the possibilities of making a good story out of his narration, and the Galatians were never free from sensitivity to the presence of story-like structures, or from having their expectations raised by them. This does not mean that Paul was obliged to conform to a set of ideal rules, to be sure, but it does suggest that even his departures from expected patterns of storytelling may signal his special concerns. ${ }^{26}$

A second presupposition is that Paul wrote the narrative sections of Galatians to serve well defined rhetorical (or pastoral) ends. While this needs little defence within the milieu of Pauline studies, scholars specialising in narrative criticism have been less comfortable with the central concerns of rhetoric, often shying away from talk about authorial purpose and text-external situation, or from the thought that narrative texts might convey specific messages. ${ }^{27}$ But there is no reason to suppose that rhetorical shaping and good storytelling cannot go hand in hand, particularly in the case of narratives embedded within an epistle like Galatians. ${ }^{28}$ The two interests do not need to coincide, of course, but why should they not often do so? To restate this claim in terms of audience perspective, there is no reason to think that the

25 As has been argued with respect to the structural conventions of classical rhetoric (Philip H. Kern, Rhetoric and Galatians: Assessing an approach to Paul's epistle [Cambridge: CUP, 1998]: 12-14).

26 Cf. Scholes: 'If we find no story, or a partial story, that, too, is a significant result' (Semiotics: 89).

27 Rhetorical critics, for their part, have no problem seeing narrative as integral to their concerns. The narratio, or narration of relevant events, is an important component of classical rhetoric and, with respect to a wider range of ancient narrative, scholars often explore the persuasive strategies of classical biography, autobiography, and history.

28 Narrative critical reluctance to pursue questions of intention and text-external situation has typically been rooted in formalist literary theory. A question frequently put to interpreters who adopt this approach is whether such theory is appropriate to the genres of NT literature. 
Galatians would not be reading or listening to Paul's narrative with story-hearing expectations as well as those that would attend hearing a rhetorical appeal. ${ }^{29}$

\section{Plot Structures}

If we look for plot in the sense of a series of causally related events that raise expectations and draw the reader towards an end, or that display tension moving toward resolution, we do not find a single, unified story running through the whole of Galatians 1:13-2:21. Instead there are three distinct stories, each with its own plot and, in some cases, subplot.

\subsection{Paul's Conversion: A Broken Story (1:13-24)}

In this section Paul appears to begin a story about his conversion. He raises expectations by first describing his way of life in Judaism, then introducing an event that can only be seen as a head-on challenge to that life. But then the story abruptly breaks off. What follows is plotless narration concerning Paul's travels. ${ }^{30}$ Nevertheless, at the end of the section Paul does offer (belatedly and indirectly) what might be called a resolution to the tension introduced near the start.

Beginning (13-14)

Entrance of tension (15-16a)

Break to plotless narration (16b-24)

Belated resolution? (23-24)
Paul's life in Judaism: zeal and persecution of the church.

Revelation of Jesus to Paul.

Paul's travels.

Paul preaching the faith he formerly attacked.

29 In addition to rhetorical and story shaping, the events that actually occurred form a third factor accounting for the composition of the Galatians narrative. While rhetorical and story interests will have affected the selection, completeness, and presentation of events, neither of these two interests need be viewed as prejudicial to a reliable account of what happened (contra Robert G. Hall, 'Historical Inference and Rhetorical Effect: Another Look at Galatians 1 and 2' in Duane F. Watson, Persuasive Artistry: Studies in New Testament Rhetoric in Honor of George A. Kennedy [Sheffield: JSOT, 1991]: 308-20, and Lauri Thurén, 'Was Paul Angry? Derhetorizing Galatians' in Stanley E. Porter and Dennis L. Stamps [eds], The Rhetorical Interpretation of Scripture: Essays from the 1996 Malibu Conference [Sheffield: SAP, 1999]: 302-20).

30 Plotless when measured by the model outlined above, at least. Some theorists would argue that plotless narrative is impossible, on the grounds that whatever structure a narrative has can be called its plot. See Chatman, Story: 47-48. 
This analysis can be clarified and supported by answering three questions. First, does Paul really begin a clearly plotted conversion story in 1:13-16a? Several narrative features indicate that he does. (1) Paul highlights the extreme other-than-Christian nature of his former life. (2) He places ö $\tau \varepsilon \delta \dot{\varepsilon}$ ('but when') at the beginning of verse 15 , signalling the arrival of something that will contrast with the life he has just described. (3) He introduces an event - a God-given revelation of Jesus - that is inherently tension filled given his activities as a persecutor. (4) He introduces this event in a subordinate clause, leading readers to expect a main clause telling what happened at or as a result of that revelation. (5) He further raises readers' expectations concerning the outcome of that revelation by describing God as the one who has called him by grace, and by indicating that God's purpose in revealing Jesus to him was that he might preach him among the Gentiles. These features lead the reader to expect 15-16a to conclude by portraying the reversal of 13-14 (either 'I stopped persecuting' or 'I stopped depending on my excellent Judaism'), or at least by portraying the fulfilment of God's intention that Paul should preach the gospel to the Gentiles. But the narrative does none of these things.

Alternative explanations that would de-emphasise the conversionstory character of 13-16 are inadequate. One such alternative would be to suggest that Paul is simply setting the stage for the following account of his post-conversion travels. But if this were the case he would not need to stress his persecuting activity and advanced standing in Judaism. Another unsatisfactory explanation would be to say that already in 13-14 Paul is amassing evidence to support the claim that he could not have received his gospel from human sources (1:11-12). ${ }^{31}$ This suggestion fails to account for the way Paul emphasises his religious standing in Judaism - why should that isolate him from Christian witness? Neither does it convincingly account for his description of his persecuting activity; while church persecution would no doubt have put him outside the normal orbit for receiving gospel instruction, Paul does not directly make this point. Was Paul's account of his race and origin simply a conventional element of encomiastic rhetoric, ${ }^{32}$ or was he perhaps responding to the charge that he never had

31 E.g. Bonnard, Galates: 29.

32 Hester, 'Blame': 298-99. 
been a good Jew? ${ }^{33}$ Maybe so, but suggestions like these do not explain why Paul has structured his narrative as he has.

Second, is it correct to say that in verses verses 16b-24 Paul breaks to plotless narration? Yes, because the narrated events are only temporally linked. They are not causally connected, either to the preceding events in verses 13-16a or to one another, and there is no longer any pull toward an end or tension moving toward resolution. Narratologists speak of a post hoc ergo propter hoc ('after this therefore because of this') effect whereby readers naturally supply logical connections even when these are not explicit in the text, but not even this works when it comes to the actions and non-actions recounted in verses 16b-24. Many interpreters read 17b, 'I went into Arabia and then returned to Damascus', as a portrayal of Paul's obedience to God's call to preach the gospel. ${ }^{34}$ But this works against the shaping of the text. Paul first highlights two things he did not do following his conversion (vv. 16b-17a); only then does he speak of going to Arabia and Damascus. He mentions neither preaching nor Gentiles in connection with those locations. ${ }^{35}$

Third, to what extent can verses $23-24$ be called a resolution to the story begun in verses 13-16a? Though the content of these verses does answer the question of how the tension implicit to the encounter between Jesus and the persecutor of his church was resolved, the explanation comes when the question is no longer in the forefront of the reader's mind. Paul's primary concern here is simply to qualify his claim that the Judean churches did not know him. He does this by saying he was known by reputation, and that in a positive way. Nevertheless, at some secondary level, perhaps sensed by both Paul and his readers, these verses do seem to provide closure to the tension set up at the start of the narrative.

What is the overall effect of this broken plot structure? The abrupt jump to Paul's travels, with all their emphasis on his minimal contact with the Jerusalem church, ${ }^{36}$ calls the reader's or listener's attention to

33 R. Longenecker, Galatians: 26-27.

34 E.g. B. R. Gaventa, 'Galatians': 315; Hall, 'Historical': 318-19; Lührmann, Galatians: 29-32; Lyons, Autobiography: 171; Martyn, Galatians: 155.

35 The issue here is not the historical one of whether Paul preached to Gentiles during his stay in Arabia, but what he highlights through the way he tells his story.

36 Paul's two statements about not consulting with flesh and blood (16b) and not going to Jerusalem (17a) are telling in this regard, as is the solemn affirmation that he is not lying with respect to his minimal contacts with the Jerusalem apostles (20). 
this distance-from-Jerusalem theme and strongly suggests that this is what Paul is most concerned to communicate. Motifs relating to beforeand-after change are present, but fall into second place. When he might so easily have arranged his narrative to highlight the miraculous transformation of a tradition zealous persecutor of the church, Paul turns away to emphasise something quite different, that he did not consult with human teachers.

\subsection{Paul's Second Jerusalem Visit (2:1-10)}

This section is unified by a central plotline. It concerns a problem, Paul's uncertainty over whether the Jerusalem apostles will accept his gospel and mission to the Gentiles, and its resolution. Paul states this problem as his reason for laying his gospel before the Jerusalem apostles. The structure of verses 1-2 suggests that this uncertainty (in conjunction with the revelation Paul mentions) motivates the whole Jerusalem visit. The tension that drives the plot is thus present from the very start. It does not carry over from the preceding section, however, nor does it logically follow from any prior narrative action; to this extent we might say the story begins in medias res ('into the midst of things'). The resolution comes in two parts, the first of which is elaborated by a subsidiary episode.

Motivated action (1-2)

Motivating tension (2b)

Resolution, part one (3-5)
Paul goes to Jerusalem and presents his gospel to the Jerusalem apostles.

Will the Jerusalem apostles accept Paul's gospel and mission to the Gentiles?

Titus not compelled to be circumcised.

Subsidiary episode: the Titus incident:

Resolution (3)

Entrance of tension (4)

Action (5)

Resolution, part two (6-10)
Titus not compelled to be circumcised.

False brothers infiltrate.

Paul resists them.

The Jerusalem apostles recognise the grace given to Paul and approve of his mission to the Gentiles. 
If the outline above seems jumbled, so does the narrative, at least by the standards of elegant storytelling. The following observations might explain some of Paul's choices. (1) That he jumps straight into the action ('I went up to Jerusalem...') before describing its motivating cause enables Paul to continue the pattern of travel narration that he has already established in the preceding section. (2) It is true that the twopart resolution seems clumsy, with a secondary episode about Titus (vv. 3-5) inserted before the main resolution in 6-10. But the Titus incident provides a concrete example that is particularly relevant to the Galatian situation. ${ }^{37}$ Its appearance here thus contributes to Paul's overall pastoral aims and lets his readers see precisely what was at stake when the Jerusalem apostles considered his gospel to the Gentiles. (3) To begin the subsidiary Titus episode with its resolution is awkward with respect to that brief story's own internal structure - all the more so since this is the first time circumcision is even mentioned in Galatians. But the way Paul tells the Titus story makes good sense when we consider its function within the flow of the larger narrative of 2:1-10. By immediately announcing that Titus was not compelled to be circumcised Paul places this fact in an emphatic position, helping his readers see that it forms an initial answer to the tension described in the immediately preceding verse. ${ }^{38}$ (4) It would be too much to claim that Paul's choice to begin the Titus subplot with its resolution fully explains his broken grammar when he then moves back one step to describe the conflict that led up to that denouement (v. 4). ${ }^{39}$ Nevertheless, the abbreviated syntax appears somewhat less surprising when we recognise that Paul is backtracking to fill a narrative gap he has created in the course of pursuing his primary rhetorical aim. There is no need to suppose that the rough grammar somehow reflects a situation in which Titus had, in fact, been circumcised. ${ }^{40}$

The principal resolution to the tension depicted in verse $2 b$, however, is quite straightforward with respect to plot structure. Paul's

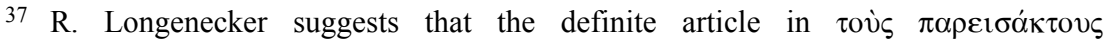
$\psi \varepsilon v \delta \alpha \delta \varepsilon \dot{\lambda} \phi$ ov implies their similarity to those troubling the Galatians (Galatians: 51 ). 38 The adversative $\dot{\alpha} \lambda \lambda \dot{\alpha}$ appropriately signals that Titus's exemption from circumcision marks an initial resolution to the uncertainty portrayed in verse 2 .

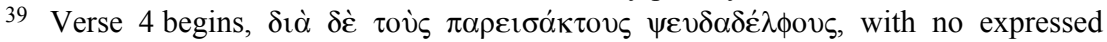
subject or main verb.

40 A theory that neither the grammar nor logic of vv. 3-5 support in any case. See the discussion in R. Longenecker, Galatians: 50. 
portrayal of the recognition he received from James, Peter and John brings the story to a clear and satisfying conclusion.

Given that one central plot unifies this section, the theme of that plot, that Paul and his gospel are approved by the Jerusalem apostles, constitutes the narrative's primary emphasis.

\subsection{The Antioch Incident: An Unfinished Story (2:11-21)}

This is in many ways a cohesive and well-structured story. When Peter comes to Antioch he enjoys table fellowship with Gentile believers; the situation is stable. Then a tension-provoking event occurs - men from James arrive. This sparks a chain of causally connected events: Peter stops eating with Gentile believers; other Jewish believers follow his example; Paul reacts by publicly rebuking Peter. Nevertheless, two departures from what we might consider ideal form mark this episode. First, as Paul starts his narrative, he immediately makes a terse statement about his rebuke of Peter. Only then does he back up and begin a temporally and logically ordered account of the events leading up to that moment of confrontation. Second and more important, after raising curiosity by depicting rising tension in Antioch Paul does not tell his readers how this conflict ends.

Preview of key act (11)

Beginning (12a)

Entrance of tension (12b)

Motivated actions (12c-21)
Paul confronts Peter.

Peter regularly eats with Gentile believers.

Men from James arrive.

Peter withdraws from Gentiles; other Jewish believers join him; Paul confronts Peter.

Within this primary plot it is possible to isolate a subplot centring on Peter: he regularly eats with Gentile believers (stable situation); men from James come (tension); Peter gives in to their pressure and withdraws from the Gentiles (resolution). ${ }^{41}$

Should verses $15-21$ be included as part of the Antioch narrative? Probably yes. Paul's address to Peter at Antioch (which begins at verse

41 If we were to continue tracing Peter's story, we would have to say that Paul's rebuke then introduces a fresh tension which, as far as this narrative goes, is left unresolved. 
14) blends into his present epistolary address to the Galatians. ${ }^{42}$ As the passage progresses, Antioch perhaps increasingly slips from view and epistolary address increasingly comes to the fore, ${ }^{43}$ but the whole passage still works as an address to Peter. With respect to plot analysis, however, it makes little difference whether the whole of verses 15-21 is included as part of the Antioch confrontation or not. ${ }^{44}$

Why does Paul begin this narrative episode by immediately announcing his confrontation of Peter? This question is best approached by considering Paul's second (and still more striking) departure from the usual conventions of storytelling: why does he report this confrontation without going on to portray its aftermath, as reader expectations would pressure him to do? There are two ways of answering this second question, and both seem valid. We could focus on the content of Paul's rebuke (vv. 14b-21) and conclude that he takes the Antioch story only so far because it allows him to highlight and expound at some length, via his words to Peter, a number of arguments his Galatian readers need to hear in their current situation. Or we could focus on Paul's act of confronting Peter and say that he ends as he does because he wishes to call his audience's attention to something about himself: he defends the gospel even if it means confronting one of the Jerusalem apostles. Having made this point, Paul has reached what is for him the important part of his story and therefore does not need to carry it further. This latter explanation enables us to look again at the way Paul starts the Antioch narrative. There, too, he breaks with the normal conventions of well-ordered storytelling, but by doing so Paul puts his self-portrayal as one who stands firm on the issue of gospel freedom in an emphatic position. He thus ensures that readers are confronted with this picture at both the beginning and end of the story. ${ }^{45}$

42 Cf. Ezra Kok, The Truth of the Gospel: A Study in Galatians 2:15-21 (Hong Kong: Alliance Bible Seminary, 2000): 50.

43 The shift of pronouns from 'you' (v. 14) to 'we' (vv. 15-17) to 'I' (vv. 18-21) is interesting in this regard.

44 If we were analyzing Paul's portrayal of Peter the question of whether these verses should be considered part of his Antioch address would make a difference: do vv. 1517 directly characterise Peter?

45 Of course, the historical question of how the Antioch confrontation actually ended will also have influenced Paul's storytelling choices. Many scholars assume Paul stops where he does simply because the incident ended badly for him (e.g. Dunn, Galatians: 130; Martyn, Galatians: 236). Another possibility that should be considered, however, is that the situation was still in flux when Paul wrote; he was not yet ready to recount 
The content of Paul's words to Peter - the way he describes his dependence on Christ and non-dependence on the law - provokes one further observation. Through these words Paul paints a final picture of himself that amounts a complete reversal of the pre-conversion portrait he gave way back at the start of his autobiographical narration, particularly of his description of his zeal for the traditions of his fathers (1:14). If Paul's conversion story found belated and indirect resolution in 1:23-24 (the Jerusalem church hearing that Paul was now preaching the gospel), here is a further resolution, though even more belated. ${ }^{46}$

\subsection{Summarising Observations}

(1) Galatians 1:13-2:21 could be described either as rhetorically motivated narration coloured by storytelling instincts or as storytelling impacted by rhetorical priorities. Whichever way one puts it, it is clear that when Paul has to choose between story interests and rhetorical concerns, the latter win out.

(2) Plot analysis lends support to the traditional understanding of Paul's aims, especially in the crucial first episode (1:13-24), in that the broken story structure reveals his particular concern to describe his post-conversion independence from human teachers and his absence from Jerusalem.

(3) Plot analysis encourages us to see $1: 13-24 ; 2: 1-10$, and 2:11-21 as distinct stories with distinct emphases. The broken story of 1:13-24 highlights Paul's lack of extensive contact with the Jerusalem apostles, thus underlining the point he has made in 1:11-12 about the origin of his gospel. 2:1-10 concerns the recognition of that gospel, telling a story that ends with harmony and agreement between Paul and Jerusalem apostles. The structure of 2:11-21 calls attention to Paul's

the episode as a definitively ended story. This suggestion becomes particularly attractive if (as I suppose) Paul wrote Galatians before the Jerusalem Council described in Acts 15 (i.e. if Galatians 2:1-10 corresponds to Acts 11:27-30; see, e.g. R. Longenecker, Galatians: 1xxx-lxxxiii).

46 To a limited extent this connection between 1:13-14 and 2:15-21 does bring an element of unity to Paul's overall narrative. But this does not alter the more fundamental observation that the Galatians narrative comprises three distinct episodes, each with its own thematic emphasis. For one thing, there is significant textual distance between Paul's self-portrait in 2:12-21 and the tension introduced in 1:13-16a. In addition, Paul does not directly call his readers' attention to a causal link between his present attitude toward the law and his encounter with Jesus - though some of his expressions ('what I destroyed', 'I died to the law', 'I no longer live', 'what I now live') do hint at the conversion motif. 
firm stand among the apostles (thus illustrating his attitude toward the gospel), while at the same enabling Paul to set before his readers extended comments concerning the gospel (and so clarify its content). So if we ask whether Galatians 1:13-2:14 is designed to support the claim made in 1:11-12, the answer must be that 1:13-24 directly supports 1:11-12, while 2:1-10 does so only indirectly, and 2:11-14 scarcely at all. ${ }^{47}$

(4) Plot analysis does not lend strong support to the view that Paul presents himself as an illustration of the life-changing power of the gospel. If Paul wants to model the transforming effects of the gospel why does he break off his conversion story? Nevertheless, at some points the plot arrangement does suggest a secondary emphasis on Paul as a model for imitation. When Paul highlights his resistance to any compromise of gospel freedom $(2: 5,11,14)$ he no doubt wishes his audience to do the same.

(5) The way Paul elaborates the content of his response to Peter and blends it into his address to the Galatians (not breaking the flow of thought by describing the confrontation's aftermath) supports the view that Paul sees a significant parallel between the Antioch situation and the current crisis in Galatia. The awkward, precipitous insertion of the Titus episode (2:3-5) into the narrative of the Jerusalem consultation suggests that this incident, too, bore some special similarity to the Galatian situation.

\section{Paul's Self-characterisation}

\subsection{Analysis}

I will limit my analysis of character portrayal to one figure, Paul himself, and will focus on only one aspect of all that such analysis could include, a listing of the traits, qualities, and personal information revealed in the course of the narrative. Though a full narratological investigation would extend further, a simple list of traits and information displays the main lines of Paul's self-portrayal. I have

47 In addition to their primary themes these stories do also contain secondary notes. For example, 1:13-24 lightly touches on Paul's harmony with the Jerusalem church and his post-conversion transformation, while 2:1-10 offers glimpses of Paul's revelation-based independence (2a) and his aggressive defence of Gentile freedom. 
followed a three-step procedure. (1) Identifying and listing all text elements that seem to reflect self-characterisation, either by way of direct comment ('I no longer live') or indirectly through actions ('I opposed him to his face'). (2) Labelling the trait, quality, or characteristic activity each element reveals. ${ }^{48}$ (3) Grouping related traits and qualities together. While there may be differences of opinion with respect to some of the exegetical and organisational judgements I have made, I think the results give a fair picture of the general pattern of Paul's self-presentation. The traits and qualities Paul highlights fall (quite naturally, I think) into two distinct clusters, gathering around two thematic centres.

a. Paul, the gospel-justified believer

i. a former persecutor greatly persecuting the church (1:13b) destroying it $(1: 13 \mathrm{c})$

ii. excellent practitioner of Judaism advancing in Judaism beyond many... (1:14a) exceedingly zealous for the traditions... (1:14b) a Jew by birth $(2: 15 a)$ not a Gentile sinner (2:15b) even we [i.e. Jews] have believed in Christ Jesus... $(2: 16)^{49}$ if...we ourselves [i.e., Jews] have been found sinners (2:17)

iii. called by grace the one who set me apart from birth $(1: 15 a)^{50}$ and called me by his grace $(1: 15 b)$

iv. a radically changed person now preaching the faith $(1: 23)$

v. free they glorified God because of me (1:24)

our freedom that we have in Christ (2:4)

vi. justified by faith in Christ knowing that a person is justified...by faith in Christ Jesus, ${ }^{51}$ even we have believed in Christ Jesus (2:16a) that we might be justified by faith in Christ $(2: 16 \mathrm{~b})$ seeking to be justified in Christ (2:17)

vii. a Jew who puts himself in the place of Gentile sinners even we have believed in Christ Jesus...(2:16)

\footnotetext{
48 In some cases a single text element reveals more than one trait.

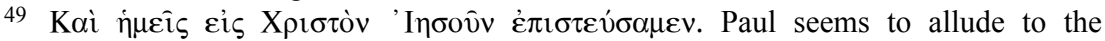
superior position of the Jews with respect to law-keeping.

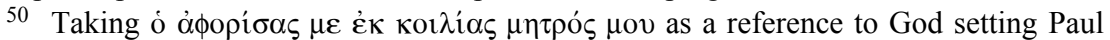
apart spiritually.

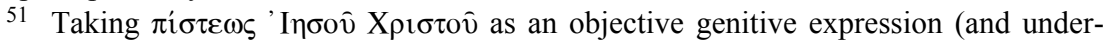

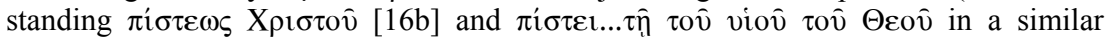
sense).
} 
we ourselves have been found sinners $(2: 17)$

viii. dead to law-dependence

knowing a person is not justified by works of the law $(2: 16)$

that which I destroyed [i.e. the law-dependence] (2:18)

I died to the law $(2: 19 a)$

I have been crucified with Christ $(2: 19 b)$

I myself no longer live $(2: 20)$

ix. does not return to law-dependence

not one who rebuilds law-dependence $(2: 18)^{52}$

I do not set aside the grace of God (2:21)

x. lives in and by Christ

that I might live to God (2:19)

Christ lives in me (2:20a)

I live by faith in the Son of God (2:20b)

xi. loved by the Son of God

...who loved me and gave himself for me $(2: 20)$

b. Paul, the authoritative, God-accredited apostle.

i. called by God

the one who set me apart from birth $(1: 15 a)$

and called me by his grace $(1: 15 b)$

ii. granted a revelation of Christ was pleased to reveal his Son to me (1:16a)

iii. commissioned to preach the gospel

that I might preach him (1:16b)

entrusted with the gospel...just as Peter (2:7)

he who worked in Peter with respect to apostleship....also worked in me $(2: 8)$

the grace given to me $(2: 9)$

iv. commissioned to preach to the Gentiles

that I might preach him among the Gentiles (1:16b)

the gospel I preach among the Gentiles $(2: 2)$

entrusted with the gospel to the uncircumcised $(2: 7)$

with respect to [my apostleship to] the Gentiles (2:8)

that we [might go] to the Gentiles (2:9)

v. not taught by human teachers or closely connected to Jerusalem

[Paul's emphasis throughout the travel accounts, 1:16b-24]

vi. not under the authority or direction of the Jerusalem apostles

I went up because of a revelation [i.e. under God's guidance] $(2: 2)$

what they were makes no difference to me (2:6)

the very thing I was eager to do [i.e. not something I was compelled to do] $(2: 10)$

vii. seeking and valuing the approval of the Jerusalem apostles

I set before them the gospel I preach...lest I should be running... in vain $(2: 2)$

viii. approved by the Jerusalem apostles

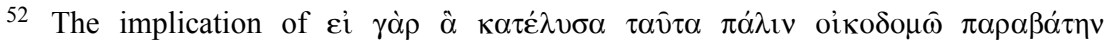

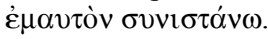


those seeming to be something added nothing to me (2:6) seeing that I had been entrusted with the gospel (2:7) knowing the grace given to me (2:9a) gave me and Barnabas the right hand of fellowship (2:9b)

ix. a bold defender of gospel truth we did not submit to them for an hour $(2: 5)$

I opposed him [Peter] to his face $(2: 11)$

I said to Cephas in front of everyone...(2:14)

$\mathrm{x}$. willing and able to confront the Jerusalem apostles

I opposed him [Peter] to his face $(2: 11)$

I said to Cephas in front of everyone...(2:14)

xi. a team leader

taking along Titus also (2:1)

\subsection{Observations}

Analysis of Paul's self-characterisation throws additional light on the results of our earlier examination of plot structure.

(1) If plot analysis indicates that Paul only secondarily offers himself as a model for imitation, that fact that his self-characterisation gives such emphasis to his status as a gospel-justified believer requires us to reconsider the degree to which he aims to present himself as an example. Paul does strongly highlight his basic relationship to God. This is almost certainly intended to provide a model. ${ }^{53}$ Character analysis reveals things that simple plot analysis does not largely because of Paul's narrative style. He engages in a great deal of character portrayal that is somewhat extraneous to the main flow of narrative action - a 'telling' rather than 'showing' manner of characterisation. Some of this 'telling' comes in the course of Paul's extended address to Peter (2:14-21), which despite its Antioch setting also functions much like direct comment to the reader. Some comes through a simple abundance of character-revealing detail. ${ }^{54}$

(2) Character analysis not only enables us to appreciate the extent to which Paul uses himself as a model, it also clarifies the precise focus of this modelling. Paul does not draw the reader's attention to the general ethos of his life or to the transforming power of God or the gospel, but concentrates sharply on one aspect of his life, his dependence on faith

53 Especially in light of 4:12.

54 As when Paul says essentially the same thing twice: 'greatly persecuting the church' (1:13b) and 'destroying it' (1:13c); 'advancing in Judaism beyond many' (1:14a) and 'exceedingly zealous for the traditions' (1:14b). 
and non-dependence on law for justification. ${ }^{55}$ Within the cluster of text elements that reveal Paul as a gospel-justified believer, the specific function of his pre-conversion portrait as an excellent practitioner of Judaism also becomes apparent. We could call it an 'even me' argument: if even such a zealous and privileged Jew as Paul depends on faith in Christ for justification, all the more so should the Galatians.

(3) That Paul portrays himself as an authoritative, God-accredited apostle coheres with and reinforces the primary thematic emphases that emerge from an analysis of plot structure: he is not dependent on the Jerusalem apostles, his law-free gospel is approved by them, he boldly defends the gospel. One difference between the text elements that contribute to the portrait of Paul as an authoritative, God-accredited apostle and those that contribute to his picture as a gospel-justified believer is that many of the former are more closely integrated with narrative events. Paul's independence, for example, is indirectly shown through the travel events of $1: 16 \mathrm{~b}-24$. His approved status emerges from the central plot events of 2:6-9, and his character as a defender of gospel truth from the acts recounted in 2:5, 11, and 14 .

(4) The large number of characterising details that relate to Paul's apostolic actions and status supports the traditional view (that Paul is concerned with legitimacy and authority) over against the view that he presents a general paradigm illustrating how the tradition-transcending gospel impacts all believers.

(5) The distribution of data relating to traits and qualities that reveal Paul as an authoritative, God-accredited apostle roughly confirms the conclusion reached through plot analysis, that each of the three narrative sub-sections carries its own distinctive emphasis. Much of the data relating to Paul's calling and distance from the Jerusalem apostles occurs in 1:15-24; data concerning his acceptance concentrates in 2:110 ; and traits relating to his defence of the gospel concentrate in 2:1114. Nevertheless, the spread of characterisation data also reveals unifying threads that tie the overall narrative together. First, the material that contributes to the picture of Paul as a gospel-justified believer clusters at the very beginning of the first sub-section (1:13-14) and the end of the third (2:15-21). Second, traits and qualities that relate to the primary theme of one sub-section sometimes make a brief

55 Though in 2:5, 11 and 14 Paul probably aims in part to offer another aspect of his life, resilience to pressure, as a model to be emulated. 
appearance in another section. For example, Paul inserts a hint about his independence in 2:2, a reference to his gospel-based freedom in $2: 4$, and a glimpse of his firmness in defending gospel in 2:5.

\section{Conclusion}

The preceding analysis of plot and characterisation leads to these principal results. (1) It supports the traditional view that the Galatians 1-2 narrative serves primarily to establish the credentials of Paul and his gospel. (2) It shows that these chapters also serve a strong paradigmatic purpose, however, thus lending partial support to the proposals of those recent scholars who argue that Paul's autobiography functions as an example. The paradigmatic function nevertheless appears to be secondary. (3) Analysis of plot and characterisation helps to refine both the traditional view (by clarifying each episode's distinct contribution to the defence of Paul's gospel and authority) and the example view (by identifying the precise aspects of Paul's life that are presented for imitation). (4) Analysis of plot structure and character portrayal offers little support to the view that Paul wishes to illustrate the gospel's tradition-transcending or life-transforming nature.

As for the method itself - whether examining plot and characterisation leads to findings that other exegetical procedures miss - I think the primary value of this kind of analysis comes through its fresh way of arranging data obtained by traditional exegesis. Examining plot structures and sorting elements of character portrayal allows certain features of the text to stand out more clearly. Where there is an ongoing lack of consensus about the function of a narrative passage, as in the case of Galatians 1 and 2, this contribution should not be neglected or undervalued.

Finally, how does analysis of plot and character relate to two other strategies that have played an important role in the interpretation of Galatians, 'mirror reading' and rhetorical analysis? In both cases narrative analysis is a useful first step. Before either practising or rejecting mirror reading - the reconstruction of the Galatian situation based on how Paul addresses his readers - one must have as clear a view as possible of what appears on the mirror's surface. A close look at narrative features contributes to this. Plot analysis cannot determine whether opponents accused Paul of dependence on the Jerusalem 
apostles, but it can clarify that Paul broke off his conversion story in a surprising manner to tell about his distance from Jerusalem. It cannot say whether the false brothers who wanted Titus to be circumcised had links with Paul's opponents in Galatia, but it does show that Paul introduces this incident into his story in a rather abrupt fashion. Storytelling moves such as these invite some kind of explanation and may well provide clues about what lies in the background. ${ }^{56}$

Scholars who analyse the rhetoric of Galatians, whether they are trying to align Galatians with the structural conventions of classical rhetoric or examining Paul's persuasive strategies more broadly in the light of Greco-Roman rhetorical and literary techniques, likewise depend on a clear sense of the text. This should include sensitivity to plot arrangement and characterisation, features that have much to do with how a narrative text will affect and influence its audience.

56 Nanos offers helpful cautions about moving from narrative to background situation, but goes too far when he argues that the narrative sections of Galatians can only be used for testing hypotheses, not constructing them (Irony: 62-72). For more on the methodological challenges of mirror reading see J. Barclay, 'Mirror-Reading a Polemic Letter: Galatians as a Test Case', JSNT 31 (1987): 73-93. 